\title{
Acid-base monitoring of open-heart surgery
}

\author{
H. G. MORGAN, R. R. OGILVIE, AND W. F. WALKER \\ From the Departments of Pathology and Surgery of the University of St. Andrews \\ at the Royal Infirmary, Dundee
}

SYNOPSIS The techniques and interpretation of acid-base studies on patients undergoing open-heart surgery with extracorporeal circulation are described. The 'normal' range and duration of changes in 35 surviving patients are given; these were essentially of respiratory rather than of metabolic origin, being a respiratory alkalosis induced by the anaesthetist before perfusion, and a respiratory acidosis after assisted respiration was stopped. Gross metabolic acidosis was seen only where clinically severe complications had occurred.

Open-heart surgery in man using extracorporeal circulation is now a common procedure in the United Kingdom, but until recently there has been little published information from the British centres on the biochemical responses to such operations. A detailed study in the immediately post-operative period was therefore carried out to define the range and duration of acid-base and other biochemical changes which might be expected (Walker, Morgan, Breckenridge, Watt, Ogilvie, and Douglas, 1963). This was felt to be particularly opportune now that the techniques and equipment are more standardized.

Previous studies on extracorporeal circulation had shown the main biochemical response to be an alteration in blood $p \mathrm{H}$, in part 'respiratory' and in part 'metabolic' in origin. Especially dangerous was metabolic acidosis, which occurred some three hours after perfusion (Ito, Faulkner, and Kolff, 1957), attributed mainly to low rates of perfusion or low cardiac output with consequent tissue hypoxia and the accumulation of acid metabolites. Although improved techniques have diminished the incidence of metabolic acidosis, problems in acid-base metabolism still occur and require careful analysis and treatment. In this paper we present our further experience on acid-base monitoring of open-heart surgery.

\section{METHODS}

Details of the earlier part of our study are given by Walker et al. (1963), and our subsequent work has confirmed the utility of our approach as briefly detailed here. Blood samples are drawn anaerobically from an indwelling arterial cannula (used for monitoring of pressures) into a siliconed heparinized $(5,000 \mathrm{u}$. per ml.) syringe, static fluid having first been cleared from the cannula.
Fluoride is not used (Siggaard-Andersen, 1961). Samples are taken every 10 to 15 minutes during perfusion, immediately after, and usually hourly thereafter. Blood is at once expressed gently into a $4 \mathrm{ml}$. bottle until this is completely full (for $\mathrm{CO}_{2}$ content) and most of the residue into a standard bottle (for haematocrit and ordinary chemistry) leaving 1 to $2 \mathrm{ml}$. in the syringe, which is capped until used to determine the $p \mathrm{H}$ of whole blood.

Estimation of the whole-blood $p \mathrm{H}$ is carried out within five to 10 minutes, because of the drop in $p \mathrm{H}$ that occurs with time. Clinically negligible falls, under $0.02 p \mathrm{H}$, occur over about 30 minutes if the blood is kept at room temperature, and over one to two hours if kept in iced water, but the $p \mathrm{H}$ falls by about 0.001 per minute at $38^{\circ} \mathrm{C}$.

The $p \mathrm{H}$ meter mainly used is that of the British Electronics Instruments Ltd. no. 48A. Blood is sucked into a capillary electrode immersed in a water-bath accurately controlled at $37 \cdot 5^{\circ} \mathrm{C}$., as the $p \mathrm{H}$ of whole blood alters by $0.015 \mathrm{pH}$ per ${ }^{\circ} \mathrm{C}$. (Faulkner, 1961). The electrode is frequently calibrated with at least two standard phosphate buffers, 6.840 and 7.416 (Mattock, 1959, 1961 ; E.I.L. booklet) or 7.382 (Bower, Paabo, and Bates, 1961) to a maximum difference of $0.02 \mathrm{pH}$, all estimations being at least in duplicate, with standardized equilibration time. Buffers and rinsing isotonic saline are also kept at $37.5^{\circ} \mathrm{C}$, and no air is sucked through the electrode. No corrections are made for whole blood as against plasma (Severinghaus, Stupfel, and Bradley, 1956a and b) nor for temperature unless hypothermia had been deliberately induced (Severinghaus, 1959).

The plasma $\mathrm{CO}_{2}$ content is unaffected by the temperature of separation (Severinghaus et al., 1956a) and is estimated by the volumetric van Slyke apparatus, without correction for the dilution by heparin or for any nitrous oxide. Paraffin, in which $\mathrm{CO}_{2}$ is highly soluble, was not used (Gambino, 1961a).

By use of a nomogram (Singer and Hastings, 1948; Davenport, 1958) with the two key values for $p \mathrm{H}$ and $\mathrm{CO}_{2}$ content, figures for buffer base, change in buffer base ( $\triangle$ B.B.; 'base excess'), 'standard bicarbonate', and the 
partial pressure of $\mathrm{CO}_{2}\left(\mathrm{pCO}_{2}\right)$ are derived. The $\mathrm{pCO}_{2}$, in $\mathrm{mm}$. of $\mathrm{Hg}$, may also be calculated, aided by the table of Milch, Bane, and Roberts (1957), from the formula $\mathrm{pCO}_{2}=\mathrm{CO}_{2}$ content $/ \alpha\left(1+\right.$ antilog $\left.p \mathrm{H}-\mathrm{pK}^{\prime}\right)$ where the solubility factor $\alpha=0.030$ and $\mathrm{pK}^{\prime}=6 \cdot 10$. These nomograms and calculations are only valid when the patient's temperature is about $38^{\circ} \mathrm{C}$. and the haemoglobin is saturated with oxygen.

The convenient and portable Danish Radiometer apparatus is now also being used. ${ }^{1}$ With this, blood $p \mathrm{H}$ is read directly and again after equilibration of two further blood samples with gases at known $\mathrm{pCO}_{2}$ values. From these readings and the nomogram of Siggaard-Andersen and Engel (1960) one can easily derive the actual $\mathrm{pCO}_{2}$ and the base excess, together with any other desired indices (Astrup, Jørgenson, Siggaard-Andersen, and Engel, 1960). $\mathrm{pCO}_{2}$ can also be measured directly by the Severinghaus electrode (Woolmer, 1959; Gambino, 1961b) but we have no experience of this electrode.

\section{INTERPRETATION OF INDICES}

There is no accepted terminology for acid-base studies (Singer and Hastings, 1948; Elkington and Danowski, 1955; Astrup et al., 1960; Robinson, 1961; Creese, Neil, Ledingham, and Vere, 1962). Our use of some terms must therefore be described.

'Acidosis' is an increase, or tendency to increase, in the hydrogen ions of the blood, with an inverse change in $p \mathrm{H}$. 'Alkalosis' is the converse. Alterations in blood $p \mathrm{H}$ are the resultant of two quite distinct causes, 'respiratory' and 'metabolic', defined by changes in carbon dioxide tension and buffer base respectively. Thus $p H=\mathrm{pK}^{\prime}$ (a constant $+\log$ base/acid. Despite some vagueness, the terms respiratory and metabolic are clinically useful in diagnosis and therapy.

Blood 'carbon dioxide tension' is affected chiefly by the excretory function of the lungs, and expressed as ' $\mathrm{pCO}_{2}$ ', the partial pressure in $\mathrm{mm}$. of $\mathrm{Hg}$ or as $\alpha$ ' $\mathrm{pCO}_{2}$ ', in mMol./1.; the normal values are 40 and $1.2(0.03 \times 40)$ respectively. A raised $\mathrm{pCO}_{2}$ indicates a respiratory acidosis.

The 'buffer base' of the blood is altered by 'metabolic' acids and bases, and is the sum of the buffer anions, normally about $46 \mathrm{mEq}$./1. It consists mainly of bicarbonate and proteinate, and so varies with the haematocrit (by $0.42 \mathrm{mEq}$. per $1 \mathrm{~g}$. of $\mathrm{Hb}$ per $100 \mathrm{ml}$.); because of this it is also often expressed as a variation from a normal of zero $(\triangle$ B.B. $=$ change in buffer base; 'base excess', positive or negative). The recent neologism 'negative base excess', used to describe the degree of metabolic acidosis, is better replaced by 'base deficit'. Total buffer base is not appreciably affected by $\mathrm{pCO}_{2}$ changes, (until

'British agents, V. A. Howe \& Co. Ltd., 46 Pembridge Road, London W.11. 'compensatory' or secondary metabolic changes $\frac{\overline{\mathrm{D}}}{\mathrm{c}}$ ensue) but the distribution of its components varies $\overrightarrow{\bar{z}}$ considerably, such that the bicarbonate rises with a high $\mathrm{pCO}_{2}$ and vice versa; this of course affects the $\mathrm{CO}_{2}$ content. For example, with a $\mathrm{pCO}_{2}$ of $80 \mathrm{~mm}$. 을 $\mathrm{Hg}$, a severe respiratory acidosis, the blood $\mathrm{pH}$ will be about $7 \cdot 18$ and the $\mathrm{CO}_{2}$ content about $32 \mathrm{mMol}$./1. without any 'metabolic' change (Fig. 1, point A). ڤ

The ' $\mathrm{CO}_{2}$ content' (total $\mathrm{CO}_{2}$ ) in mMol./1. con- $-\overrightarrow{0}$ sists essentially of the sum of bicarbonate (about:$95 \%)$ and dissolved carbon dioxide $\left(\alpha \mathrm{pCO}_{2}\right)$ in the $\vec{\omega}$ plasma of blood collected and spun anaerobically changes in its amount cannot be used alone to dis-응 tinguish between respiratory and metabolic upsets, $\vec{\sigma}$ but together with the blood $p \mathrm{H}$ can be used to' derive any acid-base term with the aid of an appro-cr priate nomogram. We have found that of Davenport useful for a quick clinical appreciation (Fig. 1).으 Thus a qualitative and quantitative assessment canbe made of respiratory $\left(\mathrm{pCO}_{2}\right)$ and metabolic $Z$

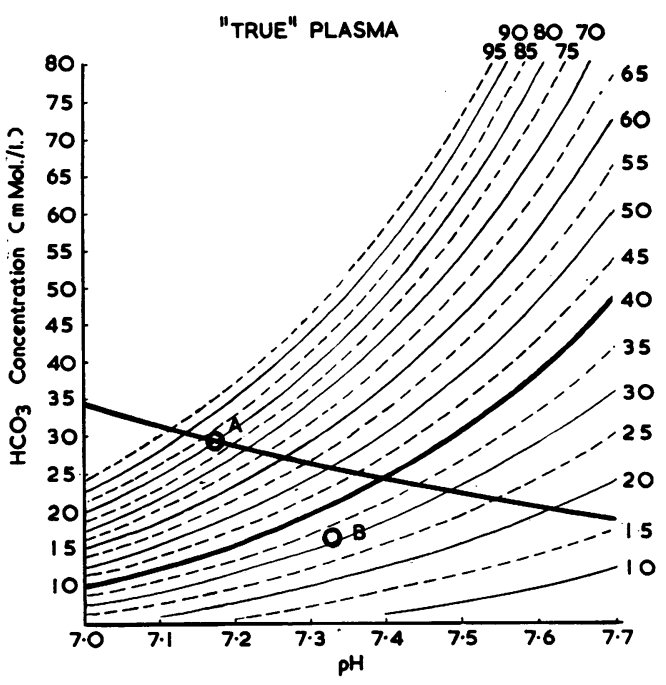

FIG. 1. A rapid evaluation of the respiratory and metabolic components of acid-base status is made by plotting a poin? from $\mathrm{pH}$ and $\mathrm{CO}_{2}$ content determinations. The respirator) component, $\mathrm{CCO}_{2}$, is then obtained by following thes appropriate curved line, the heavy black line being the normal of $40 \mathrm{~mm}$. $\mathrm{Hg}$. The metabolic component, chang@ in buffer base, is obtained by the vertical distance from the other heavy line, which represents the normal bicarbonate values of buffer base with changing $\mathrm{pCO}_{2}$. Point $\mathrm{A}$ is afe acute severe respiratory acidosis $\left(\mathrm{CO}_{2}\right.$ content $32 \mathrm{mMol}$.|l. $p \mathrm{H} \mathrm{7 \cdot 18.} \mathrm{pCO}_{2} 80 \mathrm{~mm} . \mathrm{Hg}$ ) with no change in buffer base? Point $B$ is from the fourth set of data in Fig. $5(p \mathrm{H} \mathrm{7 \cdot 32,0}$ $\mathrm{CO}_{2}$ content $16.6 \mathrm{mMol}$./l., and $\mathrm{pCO}_{2}$ therefore $31 \mathrm{~mm}$ $\mathrm{Hg})$; this represents a moderate metabolic acidosis with of fall of $7 \mathrm{mEq}$. in buffer base and a respiratory alkalosis (After Davenport, 1958.) 
(buffer base) components, which, taken carefully in context with the clinical situation and other data, can lead to appropriate action. For example, tracheostomy may be needed in acute respiratory acidosis (high $\mathrm{pCO}_{2}$, normal buffer base, high $\mathrm{CO}_{2}$ content), whereas in severe metabolic acidosis (low buffer base, low $\mathrm{CO}_{2}$ content), as well as treatment of the cause, intravenous sodium bicarbonate can be given quantitatively (as a first approximation the dose could be mMol./l. of base deficit times the extracellular fluid volume in litres. The amount eventually needed depends upon clinical response, to allow for a continuing cause and because intracellular $p \mathrm{H}$ changes are largely unknown).

'Plasma bicarbonate' ('actual bicarbonate') is found by subtraction of dissolved $\mathrm{CO}_{2}$ from the $\mathrm{CO}_{2}$ content in mMol. per 1., e.g., using normal arterial values, $\mathrm{CO}_{2}$ content $(25.2)$ less $\alpha \mathrm{pCO}_{2}(0.30 \times 40 \mathrm{~mm}$. $\mathrm{Hg}=1.2)=$ bicarbonate (24). 'Standard' bicarbonate is the above under standardized conditions of $\mathrm{CO}_{2}$ tension, i.e., $\mathrm{pCO}_{2}$ of $40 \mathrm{~mm}$. $\mathrm{Hg}$ at $38^{\circ} \mathrm{C}$. and with the blood fully oxygenated; it is merely proportional to buffer base, with similar inter- pretation in representing only the metabolic component of any acid-base change and does not vary with $\mathrm{pCO}_{2}$ as does $\mathrm{CO}_{2}$ content. The ' $\mathrm{CO}_{2}$-combining power' of plasma is an obsolete technique (see Fig. 40 of Davenport, 1958) but the $\mathrm{CO}_{2}$-combining power of whole blood is identical with standard bicarbonate.

Secondary or compensatory changes can occur to primary alterations in either $\mathrm{pCO}_{2}$ or buffer base, e.g., the respiratory alkalosis from overbreathing of diabetic metabolic acidosis, which tend to restore the $p \mathrm{H}$ to normal. At times it may not be possible to distinguish between a secondary change and a mixed disturbance except by clinical judgment.

The use of simple concentration units of hydrogen ions, like other electrolytes, has been convincingly advocated in place of the inverse logarithmic or $p H$ scale (Huckabee, 1961; Campbell, Dickenson, and Slater, 1963); these units are millimicro-equivalents or nano-moles per litre, i.e., mEq. $\times$ one million, and the normal range is 36 to 44 . The main drawback to this terminology is lack of familiarity.

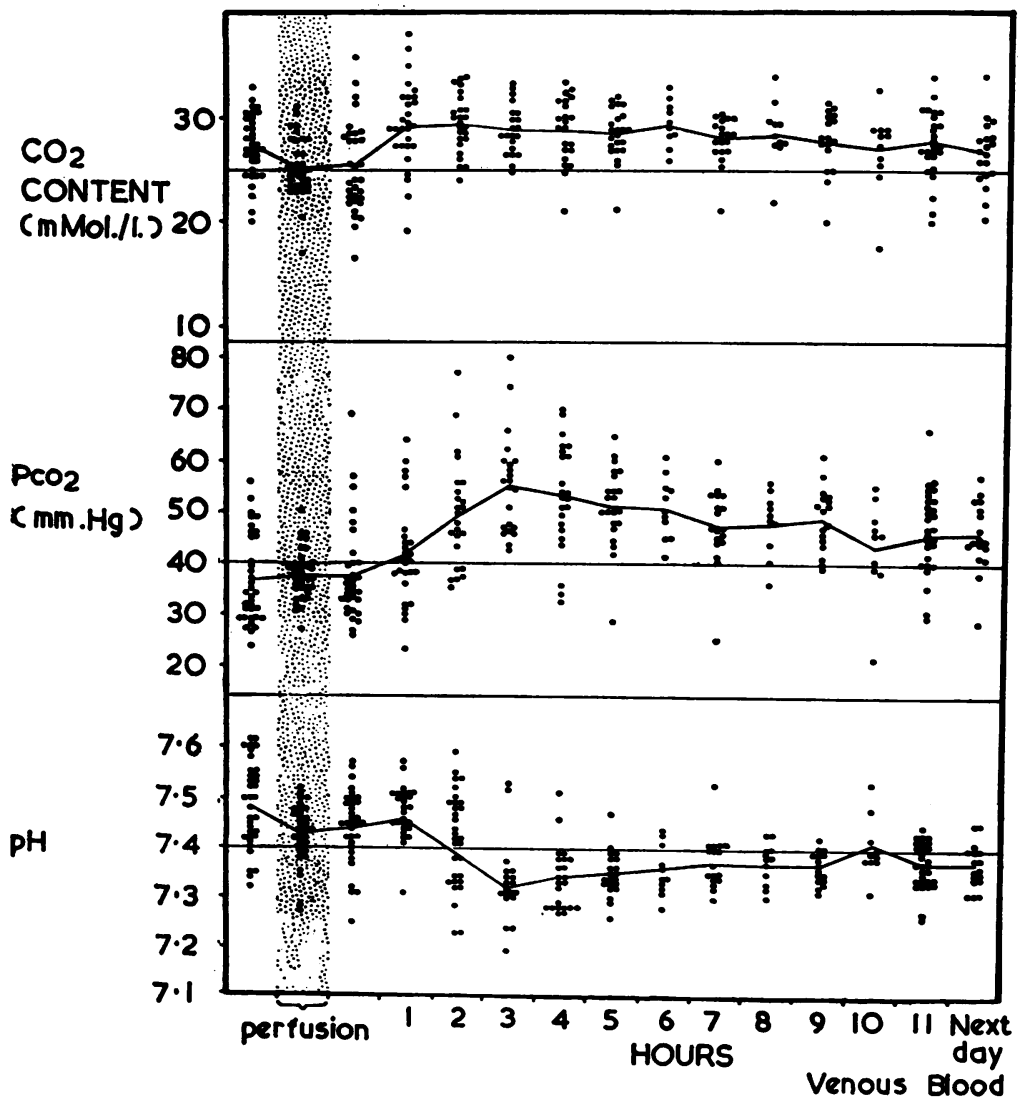

FIG. 2. Data from 35 patients before, during, and after extracorporeal circulation. Values are from arterial samples except for the 'next day' results, when venous blood was used. The principal change is a respiratory acidosis in the phase of recovery. 

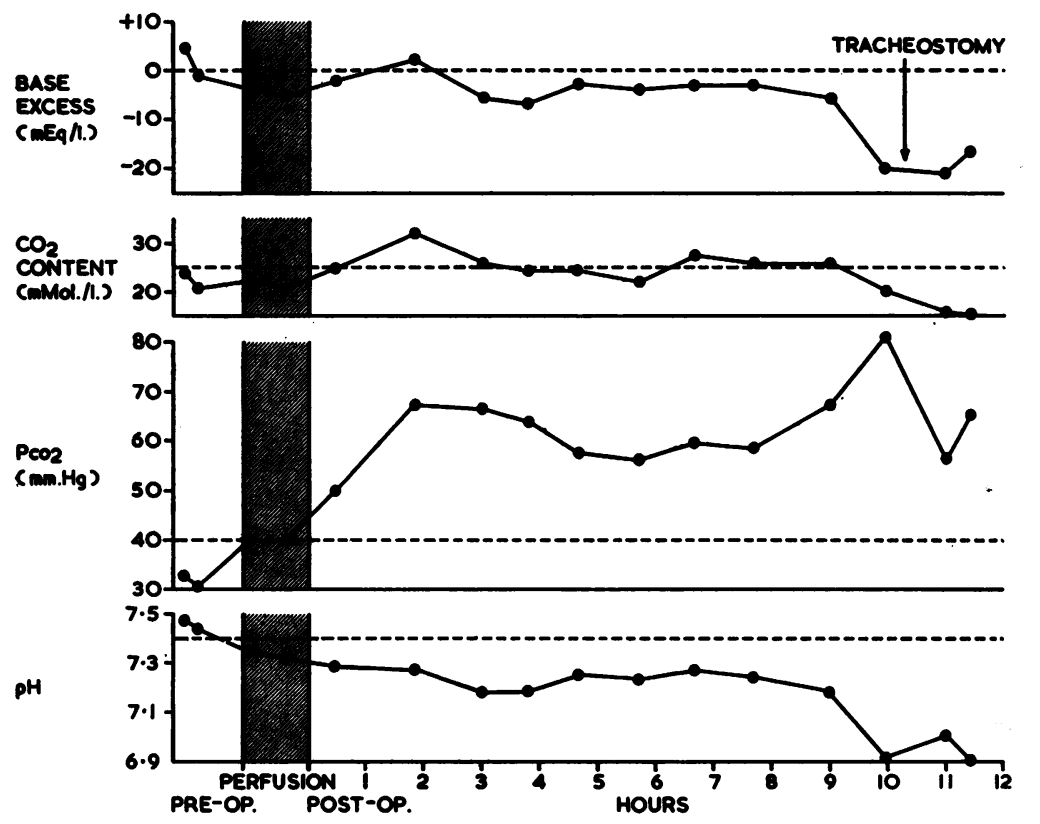

FIG. 4. Case 1. Changes in acid-base indices.

CLINICAL APPLICATIONS

The mean pattern of the changes in acid-base balance in 35 surviving patients showed four phases (Fig. 2). In the first, while the patient was under anaesthesia but before perfusion, a raised blood $p \mathrm{H}$ and lowered $\mathrm{pCO}_{2}$ indicated a respiratory alkalosis from hyperventilation deliberately produced by the anaesthetist.

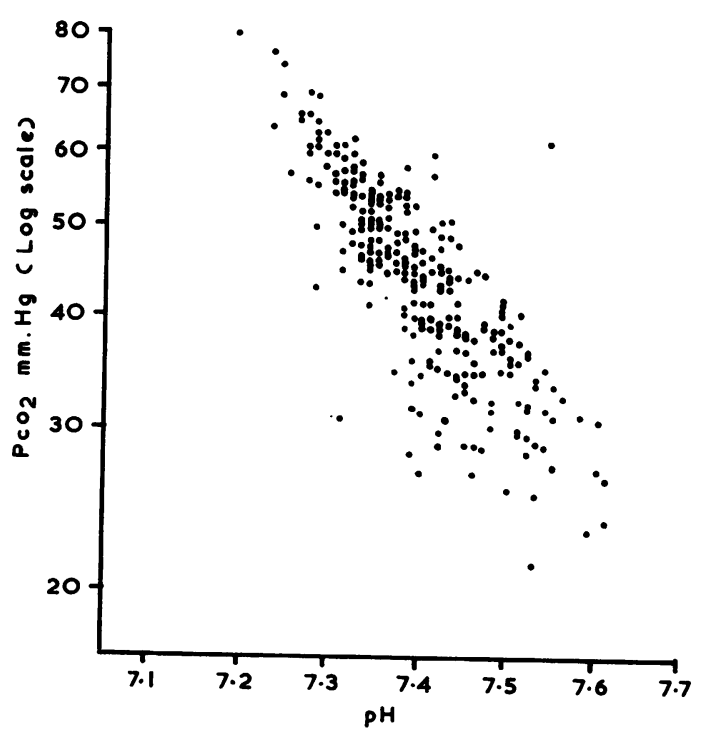

FIG. 3. This correlation between $\mathrm{pH}$ and $\log \mathrm{pCO}_{2}$ changes emphasizes that the principal cause of $\mathrm{pH}$ change was respiratory and not metabolic.
During the period of extracorporeal circulation the indices were essentially normal, with a tendency to $a_{\mathrm{c}}$ lowered $\mathrm{pCO}_{2}$ from gaseous exchange in the heartlung machine. After perfusion, but while the patiento was still under assisted respiration, the mean $\mathrm{CO}_{2} \stackrel{3}{\supset}$ tension $\left(\mathrm{pCO}_{2}\right)$ was normal, but a slight rise both in $p \mathrm{H}$ and $\mathrm{CO}_{2}$ content (and thus in buffer base) indicated a slight metabolic alkalosis.

In the fourth phase, that of recovery, the most $\overrightarrow{\vec{O}^{\prime}}$ constant finding was a high $\mathrm{pCO}_{2}$ and lowered $p \mathrm{H}, 3$ occurring soon after assisted respiration was stopped, viz., a respiratory acidosis. This gradually returned? towards normal by late evening or the following day. $\overline{\mathrm{O}}$ The parallel rise in $\mathrm{CO}_{2}$ content must not be mis- interpreted as due to any metabolic change but is 3 . due here to an altered physico-chemical equilibrium: between the two main components of buffer base $₹$ (bicarbonate and proteinate) induced by the pri-o mary change in dissolved carbon dioxide (Elkington? and Danowski, 1955; Davenport, 1958 and Fig. 1).음 Total buffer base was in fact unchanged, and therefore base excess also remained constant.

The complication which we had feared initially, $N$ severe metabolic acidosis, was not seen in this groupN of patients who survived operation, but did occur ${ }_{\sigma}$ in patients who died. This absence of metabolic acidosis (Fig. 3) is presumably due to adequate perfusion rates, absence of severe anoxia, and maintenance of normal circulation by intensive care, + including monitoring of blood pressure. It should be $-\overline{-}$ emphasized that these patients had relatively un-

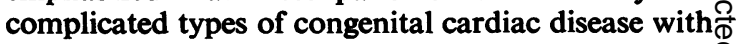
short perfusion times. 


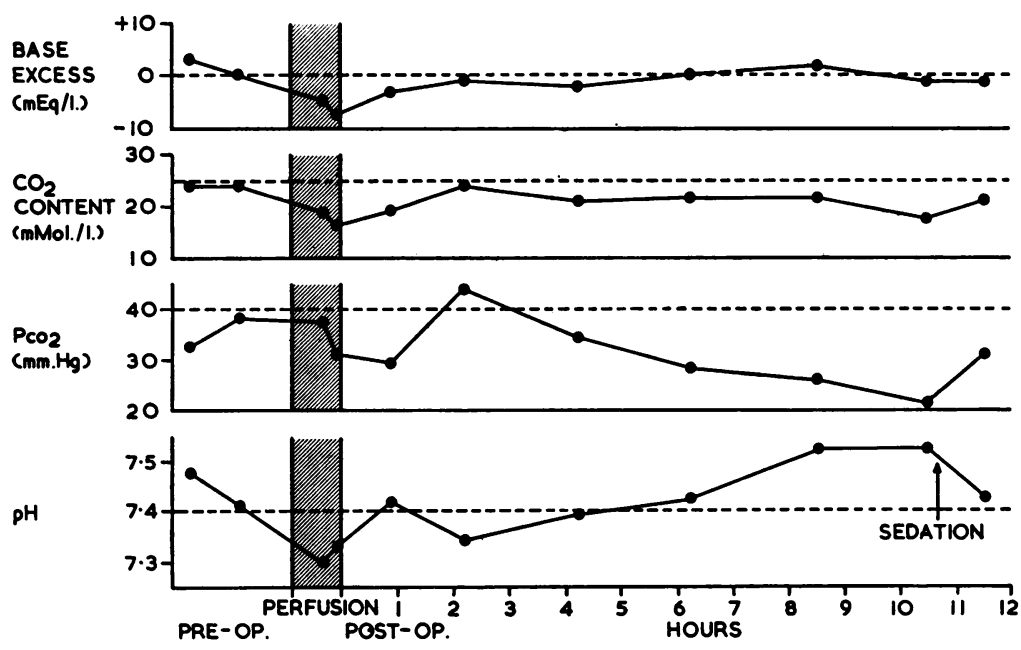

FIG. 5. Case 2. Changes in acid-base indices.

Individual variations in the usual acid-base response produced certain problems. Case 1, a 28-year-old woman, had an atrial septal defect with an unusual form of anomalous pulmonary venous drainage (Fig. 4). This was unrecognized at operation and the defect was closed, placing a great strain on the return of blood from the lungs. A slight to moderate fall in buffer base (metabolic acidosis) and rise in $\mathrm{pCO}_{2}$ (respiratory acidosis) combined to cause a considerable fall in $p \mathrm{H}$ during the following 10 hours, when, despite surgical relief of the obstruction and then tracheostomy, gross metabolic acidosis developed in association with anoxia and circulatory failure.

A second patient, a boy of 9 , had closure of an atrial septal defect with relief of pulmonary valvular stenosis (Fig. 5). In the immediate post-perfusion phase he had a low blood $p \mathrm{H}$ of mixed aetiology, a metabolic acidosis (fall in buffer base of 7 , to $38 \mathrm{mEq}$./1.) and also respiratory alkalosis (a low $\mathrm{pCO}_{2}$ around $30 \mathrm{~mm}$. $\mathrm{Hg}$ ) both of which lowered the $\mathrm{CO}_{2}$ content (Fig. 1, point B). After two hours of resuscitative therapy, the buffer base was again virtually normal but the low $\mathrm{pCO}_{2}$ persisted, with a raised blood $p \mathrm{H}$. This respiratory alkalosis was presumably due to spontaneous overventilation, which was not clinically evident. After sedation, the $\mathrm{pCO}_{2}$ rose and the $p \mathrm{H}$ fell towards normal.

In a third patient, in whom consciousness did not return after operation (probably after air embolism), coordination over 36 hours between anaesthetist and blood analyses ensured a close control of respiratory function and also of buffer base, such that the patient was given the best chance of recovery.

\section{PROBLEMS OF HYPOTHERMIA}

Deliberate cooling of the patient is now common with extracorporeal circulation in surgery of complicated cardiac defects but hypothermia raises certain fundamental problems which have not been completely solved (Brewin, Gould, Nashat, and Neil, 1955; Symposium, 1959; Neil, 1961; Marshall and Gunning, 1962). Blood gases becoming much more soluble at low temperatures, the oxygen dissociation curve of haemoglobin changes, blood $p \mathrm{H}$ itself alters by about 0.015 per ${ }^{\circ} \mathrm{C}$., the correct calculation of $\mathrm{pCO}_{2}$ becomes complex (Severinghaus et al., 1956a; Bradley, Stupfel, and Severinghaus, 1956; Severinghaus et al., 1956b) and the use of the standard nomograms, including that of Siggaard-Andersen, would be grossly misleading (Siggaard-Andersen, 1963). Physiologically, the concept of desirable 'normality' for a given temperature is still arguable (Severinghaus, 1959) and some surgeons encourage or induce acidosis during the cold phase (Edmark, 1959; Osborn, Gerbode, Johnston, Ross, Ogata, and Kerth, 1961; Carson and Morris, 1962).

In conclusion, we have found the detailed study of acid-base and other indices to be of much value in the direct clinical management of patients undergoing open-heart surgery, and indeed of other patients with severe metabolic disorders. Further, the team work which this type of study engenders is, we believe, of inestimable value to all concerned.

We wish to acknowledge the help of Miss A. Watt, B.Sc., Mrs. A. Cameron, B.Sc., Miss A. Duncan, B.Sc., and Miss A. Fitton, B.Sc., biochemists in the Departments of Surgery and Clinical Chemistry, and of Professor A. C. Lendrum who reviewed this paper. The patients were under the clinical charge of Professor D. M. Douglas.

\section{REFERENCES}

Astrup, P., Jørgenson, K., Siggaard Andersen, O., and Engel, K. (1960). Lancet, 1, 1035.

Bower, V. E., Paabo, M., and Bates, R. G. (1961). J. Res. nat. Bur. Stand., 65A, 267. 
Bradley, A. F., Stupfel, M., and Severinghaus, J. W. (1956). J. appl. Physiol., 9, 201.

Brewin, E. G., Gould, R. P., Nashat, F. S., and Neil, E. (1955) Guy's Hosp. Rep. 104, 177.

Campbell, E. J. M., Dickinson, C. J., and Slater, J. D. H. (1963) Clinical Physiology, 2nd ed. Blackwell, Oxford.

Carson, S. A., and Morris, L. E. (1962). Anesthesiology, 23, 618.

Creese, R., Neil, M. W., Ledingham, J. M., and Vere, D. W. (1962). Lancet, 1, 419 and correspondence: 1, 641, 1184, and 2, 47

Davenport, H. W. (1958). The ABC of Acid-Base Chemistry, 4th ed. University of Chicago Press, Chicago.

Edmark, K. W. (1959). Surg. Gynec. Obstet., 109, 743.

Elkington, J. R., and Danowski, T. S. (1955). The Body Fluids. Ballière, Tindall and Cox, London.

Faulkner, W. R. (1961). Cleveland Clin. Quart., 28, 116.

Gambino, S. R. (1961a). Amer. J. clin. Path., 35, 268.

(1961b). Clin.Chem., 7, 336.

Huckabee, W. E. (1961). Clin. Res., 9, 116.

Ito, I., Faulkner, W. R., and Kolff, W. J. (1957). Cleveland Clin. Quart., 24, 193.

Marshall, R., and Gunning, A. J. (1962). J. surg. Res., 2, 351.

Mattock, G. (1959). In Woolmer, R. F.: $p H$ and Blood Gas Measurement. Churchill, London.

- (1961). pH Measurement and Titration. Heywood, London.
Milch, R. A., Bane, H. N., and"Roberts, K. E. (1957). J. appl. Physiol. مِ 10, 151 .

Neil, E. (1961). In Symposium on Water and Electrolyte Metabolism, edited by C. P. Stewart and Th. Strengers, p. 143. Elsevier, Amsterdam.

Osborn, J. J., Gerbode, R., Johnston, J. B., Ross, J. K., Ogata, T. and Kerth, W. J. (1961). J. thorac. cardiovasc. Surg., 42, 462.

Robinson, J. R. (1961). Fundamentals of Acid-Base Regulation. Blackwell, Oxford.

Siggaard Andersen, O. (1961). Scand. J. clin. Lab. Invest., 13, 196 (1963). Proc. Ass. clin. Biochem., 2, 137.

- and Engel, K. (1960). Scand J. clin. Lab. Invest., 12, 177.

Singer, R. B., and Hastings, A. B. (1948). Medicine (Baltimore), 27, 223.

Severinghaus, J. W. (1959). Ann. N.Y. Acad. Sci., 80, 384.

- Stupfel, M., and Bradley, A. F. (1956a). J. appl. Physiol., 9, 189 @

-, - (1956b). Ibid., 9, 197.

Symposium on Hypothermia (1959). Ann. N.Y. Acad. Sci., 80, 285.

Walker, W. F., Morgan, H. G., Breckenridge, I. M., Watt, A. $\vec{D}$ Ogilvie, R. R., and Douglas, D. M. (1963). Scot. med. J., 8; 141.

Woolmer, R. F. (1959). Symposium on pH and Blood Gas Measure- $\mathrm{A}$ ment. Churchill, London. 